\title{
Power and Strategies in the External Stakeholder Management of Megaprojects: A Circuitry Framework
}

\author{
Johan Ninan $^{1 *}$, Ashwin Mahalingam ${ }^{2}$, and Stewart Clegg ${ }^{3,4}$
}

\begin{abstract}
Infrastructure megaprojects can cause considerable inconvenience to external stakeholders such as project communities, stakeholders in lands and stakeholders in existing services. Managing these external stakeholders is difficult as they interact with the project across permeable boundaries, are unaccountable to the requirements of the project and cannot be governed with contractual instruments or conformance to standards, as is the case with internal stakeholders. Hence the project team must resort to other strategies to manage these stakeholders. There is at present little other than scattered accounts of the use of these strategies in the literature. What is missing is a framework to explain how such strategies work to manage external stakeholders. We use organizational power theories drawn from frameworks stressing both the dimensions and the circuits of power to understand how strategy and power interact in the process of managing external stakeholders. This research uses the case study of a metro rail project in India compiled from 30 semi-structured interviews, 168 news media articles along with their 446 user comments, and 640 social media tweets along with 435 community comments. Using a qualitative research methodology, we highlight relations of persuading, framing and hegemonizing strategies employed for managing the external stakeholders in the project. Covert power-based framing and hegemonizing strategies shape the visible overt power-based persuading strategies employed to manage external stakeholders.
\end{abstract}

\section{Keywords}

Infrastructure Megaprojects, External Stakeholders, Strategies, Organizational Power

\footnotetext{
${ }^{1}$ B Bartlett School of Construction and Project Management, University College London (UCL), London WC1E6BT, United Kingdom (Corresponding Author)

${ }^{2}$ Department of Civil Engineering, Indian Institute of Technology Madras (IITM), Chennai 600036, India

${ }^{3}$ Business School, University Of Technology Sydney (UTS), Sydney, NSW 2007, Australia

${ }^{4}$ Nova School of Business and Economics, Universidade Nova de Lisboa, Lisbon, Portugal
} 


\section{Introduction}

Infrastructure is vital for the socio-economic development of any region: indeed, there is a strong correlation between the availability of infrastructure and economic growth (Queiroz and Gautam, 1992). One particular category of infrastructure projects is the 'megaproject'. Megaprojects are distinguished by being costly, colossal, controversial, captivating, complex and laden with control issues (Frick, 2008). Flyvbjerg (2014) claims that the size of infrastructure projects has grown by $1.5-2.5$ percent annually an equivalent to a doubling in project size two to three times per century - demonstrating the extent to which countries around the world are investing in megaprojects to meet infrastructure needs. These projects traditionally have been characterised by inefficiencies and failures; however, this has not stopped the number and size of these projects increasing worldwide. The poor performance of megaprojects has come in for various criticisms, notably by Flybvjerg et al. (2003). While many reasons have been posited for poor performance of megaprojects, such as optimism bias and inadequate forecasting, one factor is the inability to manage those stakeholders that are peripheral to the project: external stakeholders (Mok et al., 2015).

Mitchell et al. (1997) define a stakeholder as virtually any agency that can have an impact on an organisation's actions or that experiences an impact as a result of such actions. These agencies may be individuals, other beings or forms of collective agency, such as other organisations. Viitanen et al. (2010) define three broad categories of external and peripheral stakeholders on whom megaprojects impact: land owners or agencies from whom land is acquired; residents that are proximate to the project and troubled by construction noises, vibrations, diversions, etc., as well as those likely to benefit from the project. Other external stakeholders, such as NGOs, courts, police, media, etc., may represent the interests of these three main categories. What is evident is that normal internal governance methods, such as requirements to conform to standards or formal contract agreements, will be unavailable to oversee external stakeholders. Project teams must resort to other strategies. An understanding of the strategies used to manage megaproject external stakeholders represents a significant gap in the current literature.

External stakeholder management in infrastructure megaprojects is more complex than internal management because project teams have difficulty comprehending all stakeholder boundaries, due to the large scale of the megaproject (Mok et al., 2015) and the fact that public infrastructure megaprojects involve taxpayers' money (Flyvbjerg et al., 2009), bringing in a broad range of potential stakeholder interests. Some of these may well be reactive to the processes of the infrastructure development. When the needs and expectations of external stakeholders such as the general public or local community are ignored, they can generate social unrest or community resistance through collective action against the project (Liu et al., 2018). A recent example of this was the Melbourne east west link project which was cancelled after spending 1 billion AUD of taxpayers' money due to public protest and a change of state government. On other occasions, communities may well be proactive in proud support of the infrastructure (Söderlund et al., 2017) expressing sentiments (Ninan et al., 2019a) celebrating its achievements.

A significant gap is best filled through sophisticated theory and innovative empirics. Power theory, as the most central concept of the social sciences, is one of the most sophisticated areas of contemporary social theory approaches to interpreting empirical realities (Clegg and Haugaard, 2009). Research on infrastructure megaprojects is often criticised for excluding topics such as power, politics and conflicting interests, even when they are crucial (Clegg and Kreiner, 2013). A power theoretical perspective with its inherent focus on micro and sometimes dyadic interactions is well suited to understand the dynamics of strategies used by the project team for managing external stakeholders and how these strategies influence specific sets of behaviours. Theories of organisational power have been used to understand strategies employed to manage external stakeholders in megaprojects (Ninan et al., 2019b). In this research we further explore empirically the strategies employed in carrying out the will 
of the project team, enabling the construction of a megaproject, which we investigate through a combination of research strategies, the most innovative of which is the use of social media as a data source, along with interviews and documentary analysis of other media.

We ask the following research questions: First, (1) what dimensions of power are targeted by the strategies used for managing external stakeholders? Second, (2) how do these strategies cohere and relate to form circuits of power? In answering these questions, we first outline some major approaches to organisational power before outlining our qualitative research methodology and techniques for data collection and analysis. We employ power theory to provide a holistic framework in which to embed specific power interventions strategically. Strategy is defined by Freedman (2013) as the art of creating power. Clegg and Kornberger (2015) emphasise that strategy exist in different forms and distinguish between 'strategy' as noun, 'strategizing' as verb and 'strategic' as adjective. Anchoring strategies in discussions of power aids understanding of them as processes and practices. Based on our theoretical framing we identify three distinct strategies for managing external stakeholders: persuading strategies, framing strategies and hegemonizing strategies, corresponding to the three dimensions of power identified by Lukes (2005). Given the interdependence between the dimensions of power and consequently these strategies, we consider the relations between these strategies using a circuits of power framework (Clegg, 1989). We advance a series of propositions arising from the conjunction of our theorising and empirical analysis with which further research may be framed.

\section{Organizational Power Theories}

The use of organisational theories affords opportunity for multiple perspectives to be deployed that expand the project management research agenda (Söderlund, 2011). Given the impact, magnitude, frequency and diversity of megaproject organisations it is appropriate that they be brought into the wider purview of organisation studies (Geraldi and Söderlund,
2018). Central to the organisation studies field are concerns with power relations and strategies that structure organisation practices (Clegg and Kornberger, 2015). Contemporary social science debate has seen a number of conceptualizations of power (Lukes, 2005; Clegg et al., 2006; Clegg, 1989; Fleming and Spicer, 2014; Lukes, 1974). The most prominent distinction that has been drawn in the literature distinguishes overt or episodic dimensions of power and covert or systemic dimension of power (Schildt et al., 2019). The notion of dimensions of power was introduced by Lukes (1974) to suggest a structural model of power in three dimensions: on the surface is the exercise of power by one agency over another. Underlying this it is conceptualised that there is a second dimension in which the grounds for the exercise of power are prepared by defining what is issuable and what is not, what is up for decision-making and what is not. Confining the scope of power exercises through the exclusions afforded by signifying nonissues and non-decisions can mean that power may be exercised within what are relatively sympathetic and safe parameters for those doing the exercising (Bachrach and Baratz, 1962). The first dimension thus deals with distinct empirical episodes of power that are easily observable; for instance, when an organisation seeks compliance with its objectives, as these are decided by its decisionmaking. Once we move to consider the second dimension, power is not being explicitly exercised in specific social actions; by contrast, the power is covert or systemic, embedded in institutional structures, framing the boundaries of legitimate signification of those matters that may be raised for decision or as issues. Hence, this form of power works through intentionality in relation to what are considered normal significations. According to Lukes (1974)), the specificity of the significations that are made by agencies in second dimensional power are in turn institutionally embedded and individually embroiled by an overall framework of third dimensional power: hegemony, which frames global understandings of categories of interest. For instance, fundamental values such as constituting climate change as a matter of science or a matter of personal choice of beliefs resides herein. Hegemony, as a matter of values, 


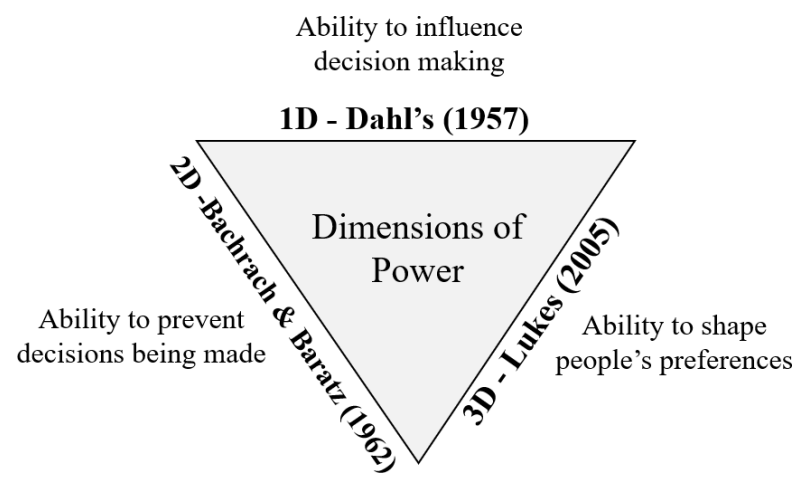

Figure 1 Dimensions of power - adapted from Lukes (2005)

is both deep seated and difficult to dislodge; for instance, climate change sceptics will not find climate science convincing any more than climate scientists will accept that their findings are a matter of belief rather than a matter of fact. Using these three dimensions can help make sense of different strategic actions (Hardy, 1996) and hence afford a holistic understanding of different strategies and forms of power in use for managing external stakeholders in the megaproject context (see Figure 1).

The first dimension of power in Lukes' categorization, an overt form of power, provides 'one with the ability to make another do something they would not otherwise do' (Dahl, 1957). The execution of this overt form of power relies on the actor's ability to mobilise resources to realise certain goals (Avelino, 2011). Power is viewed instrumentally as an actor-specific resource for achieving compliance with that actors' decisionmaking (Avelino and Rotmans, 2009). The actor may be an individual or collective agency. First dimension of power strategies explored in the literature formanaging externalstakeholdersinclude achieving adaptation, compromise, negotiation, concession and avoidance for instance on the part of another agency being targeted (Aaltonen and Sivonen, 2009; Chinyio and Akintoye, 2008). In their study of an infrastructure megaproject, Ninan et al. (2019b) observe overtly visible strategies in use, such as the use of persuasion, deputation, give and take, flexibility, and performing extra work for stakeholders. These strategies are also related to the 'fair process' approaches to managing stakeholders in the work of Kim and Mauborgne (2003).
The second dimension of power is a mix of overt and covert power and thus involves direct and indirect mobilisation of power. Commonly known as the power of non-decision making, this construct was developed by Bachrach and Baratz (1962) as they highlighted the role of agendasetting by elites and their ability to keep topics off the agenda by framing agendas so that certain issues were omitted, such that power relations managed sets of issues and non-issues. Compared to the first dimension of power there is no visible exercise of resource-based power, rather there is an implicit shaping of issues considered important in relation to their inclusion or exclusion from agendas (Fleming and Spicer, 2007). Therefore, the second dimension of power can be defined as the ability to shape agendas by preventing issues from being raised and decisions from being made. Being able to set the agenda is referred to as 'real power' by Lukes (2005) because it enables issues to be framed as legitimate and enacted (or not), and thus limits not only those issues addressed but also the range of possible solutions that a broader set of issues might engender. Strategies that are based on the second dimension of power, when employed to manage external stakeholders, include strategic misrepresentation of the benefits of the project while the costs are underplayed, leading to the selection of poor projects (Flyvbjerg et al., 2003). In the case of the 2012 London Olympics (Gil and Lundrigan, 2012), the project team minimised the Olympic Games goal (construction of stadiums) of the project and highlighted the urban regeneration goal (construction of associated infrastructure) to obtain local community support. The project sought to shape the issues associated with constructing the Olympic stadium as a benefit rather than a cost to tax-payers.

The third dimension of power is covert, expressed in the radical view of power proposed by Lukes (1974). Scholars regard this as an ultimate exercise of power that shapes preferences, attitudes and political outlook in terms of values, such that subjects come to accept situations as they are because they find it unimaginable that there could be an alternative (Lukes, 2005). Therefore, the third dimension of power can be defined as expressed in value preferences. World views such as a dominant religion or ideology 
may be a form of macro-domination expressing these values. At a less transcendent level such a state of order can be cultivated through specific corporate cultures as well as field-wide or societalwide assumptions (Fleming and Spicer, 2014). Subtle shaping of preferences in this way creates a practical hegemony (Gramsci, 1971). Strategies for managing external stakeholders based on the third dimension of power include educating the community about the benefits of a project $(\mathrm{Ng}$ and Loosemore, 2007) as well as subtle branding strategies that associate the project with desirable outcomes while glossing over those less desirable (Ninan et al., 2019a). Also, 'corporate diplomacy' (Henisz, 2017), where an organisation strives to win the hearts and minds of external stakeholders, can be used. Consequent changes in the external stakeholders' orientations to action parallel the third dimension of power discussed above.

The dimensions of power framework is a structural model that distinguishes levels of analysis but not the dynamics of the processes relating them in practice. For this attention to dynamics and processes we need to turn to the circuits of power theoretical framework (Clegg, 1989) that offers a clear mechanism for tracing the dynamics of power flowing through multiple circuits (Lapsley and Giordano, 2010), analogously to electricity. In the framework, power circulates through social relations, working practices and techniques of discipline (see Clegg, 1989, p. 214 for the circuits of power model). The model considers power as flowing through three dependent circuits integrated through obligatory passage points (OPP). Obligatory passage points are normal significations of the acceptability, appropriateness and legitimacy of actions (Callon, 1984). The first circuit, the episodic circuit, is premised on the first dimension of power (Smith et al., 2010) in which different social agents interact in predictable ways, given the stability of certain 'standing conditions'. The second circuit, the social integration circuit, focuses on the rules of meaning and membership that frame social relations. It is this circuit that provides members of organisations with accounts, resources and legitimacy to exercise power over another (Backhouse et al., 2006; Heracleous and Barrett, 2001). The third circuit, the system integration circuit, relates to innovations in techniques of discipline and production that empower or disempower differential agents (Vaara et al., 2005). Thus, overt power depends on existing institutions in the form of rules or practices, the 'deep structures' (Allen and Kern, 2001; Clegg, 1975) of everyday rationality, which are framed by the systemic circuit.

The circuits of power framework can be used to describe the processes of the empirical social fabric in which power relations operate. Each of these circuits can be considered as similar to the dimensions of power. Thus, we argue that the dimensions of power and the circuits of power can together explain external stakeholder management strategies in the context of infrastructure megaprojects.

\section{Research Methodology}

To address our research objective, we choose to conduct a single in-depth case study research of a metro rail infrastructure megaproject in India. It is being built in an existing city of about 5 million inhabitants for whom, in 2007, it was politically resolved that the current transport network in the city was inadequate to support the demands of the growing city and a metro rail was posited as the solution to that problem. The metro rail infrastructure megaproject was commissioned with a budgeted cost of USD 2.2 billion. The construction activities started in 2009 and the project was commissioned in parts from 2015 with construction in multiple stretches still in progress during the study period. For the execution of the metro rail project, a quasi-government organisation was set up as a Joint Venture (JV) with the Government of India and the State Government. Given that the metro rail is being inserted into a functioning city it is extremely disruptive of many of the existing services in the city. In consequence, these services, their providers and users, are keenly interested stakeholders in the impact of the project on their interests. Consequently, many stakeholders are enrolled into the project. Additionally, the project has multiple objectives such as reducing pollution and boosting the city's economic growth, 
enrolling other stakeholders. Politically, the project is subject to considerable pressure to maintain schedule. Taking all these factors into account, a variety of external stakeholders are demonstrably present for this project.

Three main external stakeholder groups were prevalent in case of the metro rail project considered. First, land is required for constructing the project or for providing the working space that facilitates the construction. These lands have to be acquired from multiple landowners involving government agencies, private owners and even religious groups. Mahalingam and Vyas (2011) note that the majority of the infrastructure projects in India are significantly delayed due to land acquisition issues as the process is very timeconsuming even when resistance is absent. Second, the megaproject is housed in an existing urban system disrupting many existing services during the construction and operation phases. A network of essential services such as electricity, drinking water, sewerage, telecommunication etc., and transportation services such as airports, railways, rapid transport systems, highways, etc., can be disrupted because of the megaproject and these external stakeholders need to be managed. Third, the project community involves stakeholders who are active in the area surrounding the project and who are inconvenienced due to the construction activities of the project. They are also the endusers of the project, the taxpayers who fund the project, and are also the eligible voters who change government.

The metro rail organisation was primarily responsible for engaging with these external stakeholders. A design-build contract was signed by the metro rail organisation with the main contractor thereby shifting some of the responsibilities for engaging the external stakeholders to the contractor. For example, utility relocation was formally part of the contract while small changes, such as the use of sheet piles to cause minimum disturbance to the community, were informally allotted to the contractor. The metro rail organisation cited the design-build nature of the contract and denied the cost claims attributed to such changes. However, major design changes, due to the lack of available land, for instance, were covered in cost and time variation. There were disputes as to what constituted a contractual change and what did not. Due to these issues, contract administration in this project was complicated, resulting in some contracts being terminated while, in some other instances, contractors abandoned the work and ran away.

Our aim here is to explore the external stakeholder management strategies that were used in infrastructure megaprojects. For this, we used a qualitative research methodology as it is apt for exploratory research when the aim is to generate new understandings for future research or to gain familiarity with a problem (Eisenhardt, 1989; Scott, 1965). The interview data was collected through unstructured interviews (Spradley, 1979). We chose to carry out unstructured interviews that allowed participants to lead conversation where they will (Plowman, 1998), in order to observe both overt and covert dimensions of power. We interviewed 30 project team members from different organisations and asked them about their experiences with external stakeholders. The interviews ranged from a minimum of 60 minutes to a maximum of around 180 minutes with a few participants.

In addition, we studied exchanges in news articles and social media from and about the project to understand how the project communicated with external stakeholders in order to understand the covert strategies employed to manage them. Since megaprojects have a large footprint, social media and news article communications are more effective in reaching the dispersed external stakeholders in contrast to public hearings, union meetings, etc., wherein attendance can be minimal. Given that the project team managed the projects' official page on Twitter and Facebook, social media was selected to study power in the third dimension. Through control of social media, the project team could proactively propagate communications intended to change the preferences of external stakeholders - a critical dynamic of the third dimension of power.

In contrast to social media, the mass media was not managed by the project. The current events surrounding the project were reported in news media; often, only a statement by the project spokesperson was included. These opportunities were used by the project team to frame situations to their advantage; thus, we used news articles to 
study power in the second dimension. In both these media we required only a representative sample of how the project team communicated rather than tracing all the events of the project longitudinally. Therefore, rather than collecting data for the whole lifecycle of the project, we restricted data collection to the point of reaching theoretical saturation of data. All the news articles relating to the metro rail project from first January 2017 to $31^{\text {st }}$ December 2017 were retrieved from 'Google news' to avoid bias of selection of just one media outlet. The data retrieved comprised 168 news articles and 446 user comments spanning different news media outlets. We also systematically studied social media posts from the metro rail organisation on their official twitter and Facebook pages. A total of 640 tweets from 2012-2017 and 435 community's Facebook comments from April 2017 to August 2017 were retrieved.

We adopted a qualitative research methodology to analyse the data collected systematically; the data came not only from semi-structured interviews but also included naturalistic data such as social media posts and news articles, as we have explained. We went through the interview transcripts, news articles and social media posts and looked for incidents that involve external stakeholders and the way the project team managed them. Each of these incidents were assigned a category derived from the dimensions of power approach (Lukes, 2005) - first, second, and third dimension. We also looked at how these instances were represented in the news media, social media and interview data and contrasted them. The description of instances varied across different media as the news media data was 'what was communicated strategically to external stakeholders', while our interview data gave more depth into 'what really happened on site'. In contrast to news articles published by multiple independent media houses, in which the topic under discussion, page placement, associated importance, etc., is under the control of the media house, the social media page of the metro rail project was owned and operated by the project organisation, with control vested in the metro rail organisation.

The multiple instances and their different representations in the data sources provided in-depth data on how separate instances related to each other. The relations between the structural dimensions were analysed via their dynamics in the circuits of power (Clegg, 1989). We recorded multiple instances in a tabular form following the recommendations of Eisenhardt (1989) for theory building; however, we only discuss relevant instances that substantiate the research findings and portray dramatic moments that make the story interesting (Golden-Biddle and Locke, 1997).

\section{Findings \& Discussion}

Our analysis of the strategies observed in the metro rail project in India are discussed below. We anchored analysis of these strategies in the dimensions of power framework (Lukes, 2005) and in the relation between these strategies as they flowed into each other in terms of the theory of circuits of power (Clegg, 1989).

\section{Strategies for Managing External Stakeholders}

The strategies that we observed for managing external stakeholders fell into three categories - persuading strategies, framing strategies and hegemonizing strategies. These strategies are anchored in the dimensions of power framework (Lukes, 2005) as shown in Figure 2 and are discussed in detail below.

\section{First dimension of power: Persuading Strat- egies}

Persuading strategies were used for enabling discussions with the affected external stakeholders thereby 'persuading' them to favour the project by improving coordination and speeding the approval process. These strategies, through active discussion and mutual agreement, led to external stakeholders doing what they would not have otherwise done with a negotiated order as the outcome. In the case of the metro rail project, there were visible exchanges to facilitate cooperation with the external stakeholders. For instance, the metro rail organisation agreed to construct an extra parking facility for the airport authorities in exchange for 


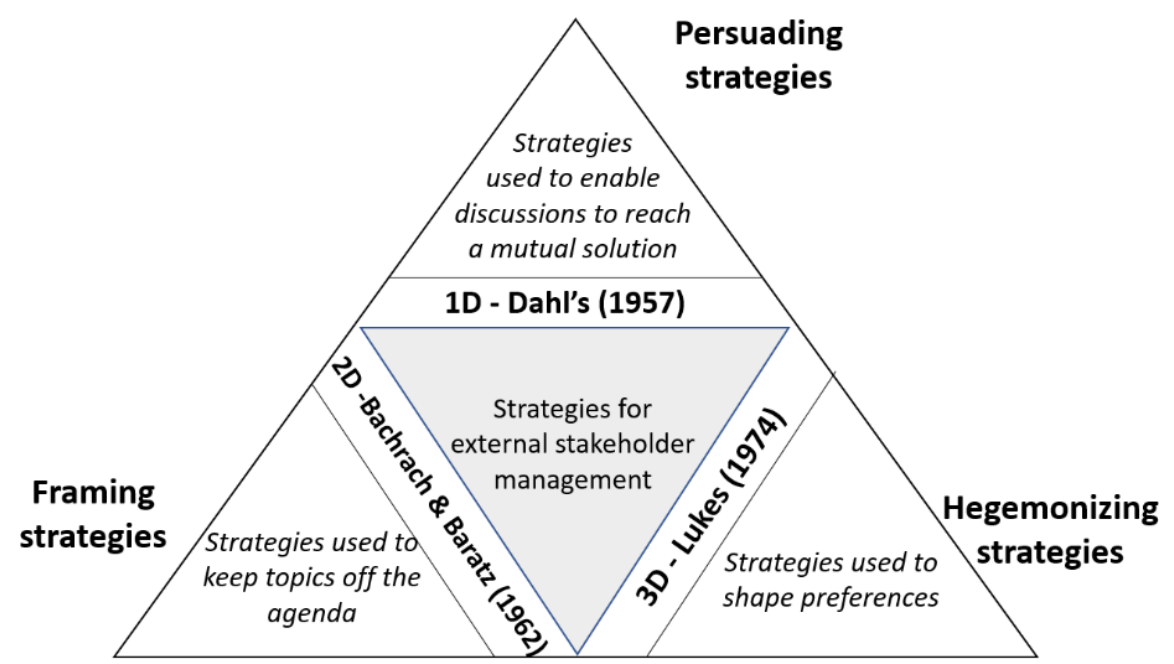

Figure 2 External stakeholder management strategies anchored in dimensions of power framework.

the permission to build the airport metro rail station in the airport land. During an interview, the design head of the metro rail organisation said,

"They [airport] also want something from us ... This [parking] is an added facility for them ... these kinds of projects work that way only ... give and take ..."

In another instance, employees were deputed from government utility agencies such as the telecom department, electricity department, water department, highway department, etc., to enable coordination during the relocation of utilities. In another instance, when landholders resisted the tunnelling activities under their property, the project team argued that, similarly to mineral resources, landholders did not have legal rights to what lay 20 metres below their land.

The dynamics of persuasion observed here underlay the first (overt) dimension of power, which depends on the actor's ability to mobilise resources to realise certain goals. In this case the goal was external stakeholder support, as Avelino (2011) notes. The extra parking facility for the airport authorities described above was possible only because the project team enjoyed fund discretion. The deputation from government agencies was possible because the project team enjoyed political backing, thereby permitting government employees to be deputed to the metro rail project. Skilled employees, able to convince external stakeholders through rational arguments, can also be a resource that can enable persuasion strategies. Thus, we posit that

Proposition 1 (P1): Persuading strategies in megaprojects depend on the resources available to the project team for external stakeholder management.

Other representative instances and quotes that can be categorised as persuading strategies are recorded in Table 1.

\section{Second Dimension of Power: Framing Strat- egies}

In any power relation there will be some parties for whom issues are legitimated while other parties will seek to delegitimize these or position other issues as more legitimate. Framing strategies were used as a strategic tool by the project team to highlight certain issues while communicating with the external stakeholders to try and make these issues seem more legitimate or important than others. In the metro rail project case, the megaproject team restrained from talking to the media in the absence of having agreed an agenda amongst themselves in advance. The public relations officer was only permitted to talk to or address the media with an agenda approved by the public relations head and Managing Director (MD) of the metro rail project. The public relations officer (PRO) of the project quoted, 
Table 1 Representative instances and quotes for persuading strategies

\begin{tabular}{|c|c|}
\hline Persuading strategy instances & Representational quotes \\
\hline $\begin{array}{l}\text { Land acquisition at market rates from private } \\
\text { landowners instead of guideline rate to avoid protests } \\
\text { during the land acquisition process }\end{array}$ & $\begin{array}{l}\text { "One ground of land in this region actually cost INR } 2 \\
\text { Crores [USD } 320,000 \text { ] while the guideline value of the } \\
\text { same was INR } 60 \text { Lakhs [USD 94,000]. We were able to } \\
\text { acquire land as we paid market prices." }\end{array}$ \\
\hline $\begin{array}{l}\text { For excavation near a busy street, project team } \\
\text { agreed to use sheet piles at extra costs instead of } \\
\text { closing the road, so that businesses along the road } \\
\text { would not be affected }\end{array}$ & $\begin{array}{l}\text { "At that location we had to dig very close to the road ... } \\
\text { normally, we excavate easily by closing the road ... but } \\
\text { we used sheet piles here, so the road won't be closed, and } \\
\text { business won't be affected" }\end{array}$ \\
\hline $\begin{array}{l}\text { Design of foundations were adjusted for utilities } \\
\text { which could not be shifted thereby speeding the } \\
\text { construction of the project }\end{array}$ & $\begin{array}{l}\text { "We [design team] will be designing piles beautifully, but } \\
\text { only once the excavation starts we will be able to know the } \\
\text { real challenges underneath ... the challenges faced mainly } \\
\text { were because of utilities and not due to ground conditions } \\
\ldots \text { we sometimes had to adjust for the utilities and use } \\
\text { eccentric foundation designs to accommodate the utilities" }\end{array}$ \\
\hline
\end{tabular}

"While talking to press, they [PR Head, MD] tell us exactly what to say and we say based on that... generally, the rule here is that no employee is supposed to talk to the press apart from the authorized spoke person"

By authorising an official spoke person to talk to the media, the project team was able to highlight certain issues while obscuring others. The project team opted to highlight salient features of the project and promoted these as innovative, community centric, pioneering, etc. On the use of solar energy in the project, the project team propagated it in the news articles as one of the largest on-site solar projects in India, as below.

"Once fully operational, the total capacity of rooftops and ground mounted power systems in *** [metro rail organization's] facilities will be six $M W$ [megawatt], which will make it one of the largest on-site solar projects in India". (Quoted from a news article of $23^{\text {rd }}$ June 2017)

The project team also stressed one of the main goals for the project - interconnectivity between existing infrastructure systems - wherever possible in news articles linking the project's initiatives to this goal. An example of this can be seen with the implementation of a common ticketing system, which is highlighted in the news article quoted below.

\section{"We [metro rail organization] are focusing a lot on implementing the common ticketing system soon. Using this, passengers can use the same card in trains, buses and even ATMs" (Quoted from a news article of 25th November 2017)}

While the project team highlighted certain issues in the news media, it did not publicise certain issues that were controversial, such as reasons for delays or the reason for accidents. Rather than accepting the blame for the accident, the project team would stress that despite taking all the precautions the accidents occurred, as reported in the news article quote below.

\section{"The workers did wear their safety gear and other safety precautions were in place. We [metro rail organization] are in the process of finding out how it happened" (Quoted from a news article of $3^{\text {rd }}$ July 2017)}

The strategic use of framing is quite similar to the findings from Kornberger and Clegg (2011), in which the media-focused and seductive language of the strategist substituted for the techno-rational discourse of the planner, thereby hiding certain 
issues. These strategies enable the project team to keep topics off the agenda (Bachrach and Baratz, 1962), restricting discussion on certain topics, in contrast with the 'persuading' strategy. It enabled the diversion of attention to issues which appeared to be more favourable to the project while others were omitted or underplayed. Thus, with the use of the framing strategy, as Fleming and Spicer (2007) note, there is an implicit shaping of issues made pertinent. Goffman (1974) claims that framing is the way something is presented to others and it affects the actions and choices individuals make. The dominant frame is an interpretation with the highest probability of being noticed, processed and accepted by most people (Entman, 1993).

These framing strategies create a positive perception of the project. The comments below the news articles showered praise on the metro rail project for being innovative. For instance, the following comment was received in response to the metro rail stations getting a green rating for initiatives such as solar power.

"Kudos. That should become trend-setter for other metro rails as well as for IR [Indian Railways] itself" (Quoted from the comments of a news article of 13th February 2017)

In a news article that recorded the metro rail organisation as providing subways for easy access for passengers to the metro stations on a busy road, a community member commented,
"Very glad to note that 4 subways are going to be thrown to public shortly. The crossing by way of roadside will be eliminated and it is a boon to public and a major relief to passengers to cross either side" (Quoted from the comments of a news article of 26 March 2017)

The role of framing strategies - partly overt but covert as well - in creating a dominant discourse in favour of an organisation is supported by the literature; for instance, Iyengar and Simon (1993) record that individuals habitually refer to events in the terms in which they have been portrayed in the news while diagnosing social and political issues. We therefore posit that,

Proposition 2 (P2): Framing strategies strive to create a favourable perception of the project in the eyes of external stakeholders

Other representative instances and quotes that can be categorised as framing strategies are recorded in Table 2.

\section{Third Dimension of Power: Hegemonizing Strategies}

Hegemonizing strategies are used to change the behaviour of the community making them subjects of power. There is a great economy to power that finds it unnecessary to intervene in existing relations because these relations already represent the situations it seeks to reproduce (Clegg, 1989).

Table 2 Representative instances and quotes for framing strategies

\begin{tabular}{|l|l|}
\hline Framing strategy instances & Representational quotes \\
\hline $\begin{array}{l}\text { The metro station under the central railway is } \\
\text { highlighted as one of the largest underground } \\
\text { transport structures in the country }\end{array}$ & $\begin{array}{l}\text { "With 3 decks, the } 390 \mathrm{~m} \text { long } 33 \mathrm{~m} \text { wide and } 28 \mathrm{~m} \\
\text { deep central metro station will be one of the largest } \\
\text { underground transport structures in the country" }\end{array}$ \\
\hline $\begin{array}{l}\text { The metro rail organisation's depot is highlighted to } \\
\text { use cutting edge technology and as only one-tenth the } \\
\text { size of depots built by railways }\end{array}$ & $\begin{array}{l}\text { "The depot, set to come up near the *** [name of the } \\
\text { place] railway station, will be one-tenth the size of } \\
\text { depots built by the railways, but will have cutting edge } \\
\text { technology for regular upkeep of trains" }\end{array}$ \\
\hline $\begin{array}{l}\text { External factors such as ground conditions beyond the } \\
\text { control of the project team is highlighted as cause of } \\
\text { road cave-in }\end{array}$ & $\begin{array}{l}\text { "The cause behind the caving in is a loose soil pocket } \\
\text { along the tunnelling alignment where the boring machine } \\
\text { is under operation" }\end{array}$ \\
\hline
\end{tabular}

Engineering Project Organization Journal

(C) 2018 Engineering Project Organization Society www.epossociety.org 
The metro rail project in their social media page appealed to the sentiments of the community. The project celebrated national festivals, hoisted flags during national days, conducted cultural events during regional festivals, and even highlighted the Corporate Social Responsibility (CSR) initiatives of the project as demonstrated by the tweet below.

Skit on Truth Alone Triumphs Performed: To mark the occasion of Vigilance awareness week ... (Tweet by the metro rail organization on $1^{\text {st }}$ November 2014)

The project also targeted sections of the population, such as college students, school children, disabled people, women, etc. and had targeted programmes to engage with them. The project took school children on joy rides on the metro rail and conducted drawing competitions with the theme 'go green metro' as highlighted in the tweet below.

Painting competition at 4pm Today!!! Topic

- Go Green Metro - Timing 4pm to 6 pm Don't forget to bring your colors. (Tweet by the metro rail organization on 4 June 2016)

All the events held were centred on the project's advantages and desirable features to embed them in the minds of the targeted populations, such as young school children. Through these events the metro rail aimed to become a lifestyle choice, acceptance of which implied learning specific rituals and disciplines (Foucault, 1977). Within megaproject research, Henisz (2016) records that managers can show empathy by understanding and appreciating local traditions and beliefs in the project community; in this case, by targeting sections of the community according to common sentiments prioritising categories of persons such as the disabled, school children and women.

These hegemonizing strategies recruited positive preferences from the community making them advocates of the project: children would come home from school as ambassadors for the project while women were attracted by the security and safety aspects of the metro. When a Facebook post by the metro rail organisation on recruiting new staff to the Public Relations (PR) team attracted some disapproval, such as "this won't bring you more crowd for metro. Reduce the ticket rate", a member of the community clarified that,

"This [recruitment of PR staff] is to have more interaction with the commuters and public to wipe out the inconveniences and to improve the efficiency of the service." (Quoted from the comments on a Facebook post of 16th September 2017)

Another community member supported the metro rail project by claiming that the delay in the project was not the project organisations fault, but it was due to land acquisition issues as recorded in the comment below,

"The delay is due to land acquisition issues .... Not tech problem" (Quoted from the comments on a Facebook post of $15^{\text {th }}$ May 2017)

This expression of a positive preference from the community resulted in the metro rail garnering more support from the community. We therefore posit that,

Proposition 3 (P3): Hegemonizing strategies seek to create community values favouring the project and aligned with the project objectives.

Other representative instances and quotes that can be categorised as hegemonizing strategies are recorded in Table 3.

\section{Relation between strategies}

To understand the relation between strategies we integrated the enablers and effects of the strategies considered in the previous section with data from interviews, news articles and social media to see how events were represented in each source. We observed framing strategies leading to persuading strategies, hegemonizing strategies leading to persuading strategies, persuading strategies leading to framing and hegemonizing strategies, and finally framing and hegemonizing strategies leading to strengthening of resources. Each of these relations are depicted in Figure 3 and discussed below. 
Table 3 Representative instances and quotes for hegemonizing strategies

\begin{tabular}{|l|l|}
\hline Hegemonizing strategy instances & Representational quotes \\
\hline $\begin{array}{l}\text { The metro rail highlighted in its social media } \\
\text { page that they are going to celebrate the Republic } \\
\text { day of India }\end{array}$ & $\begin{array}{l}* * *[\text { metro rail organisation] celebrates Republic day. *** } \\
\text { [name of Managing director], Managing Director will hoist the } \\
\text { Indian flag on the occasion of Republic day (Tweet by metro } \\
\text { rail organisation on 25 Jan 2014) }\end{array}$ \\
\hline $\begin{array}{l}\text { The metro rail promoted it giving award for } \\
\text { student volunteers who provided guidance } \\
\text { support to the project }\end{array}$ & $\begin{array}{l}\text { NSS volunteer students of *** (name of college) awarded for } \\
\text { "Traffic Management and Customer guidance support" by *** } \\
\text { (metro rail organisation) (Tweet by metro rail organisation on } \\
\text { 18 Aug 2015) }\end{array}$ \\
\hline $\begin{array}{l}\text { The project promoted its social responsibility } \\
\text { by highlighting that it conducted oral cancer } \\
\text { screening programme for their contract labourers }\end{array}$ & $\begin{array}{l}\text { "Oral Cancer Screening Programme for *** (name of metro } \\
\text { rail organisation) contract labourers - Oral Cancer Screening } \\
\text { Programme was conducted" (Tweet by metro rail organisation } \\
\text { on 8 Jan 2015) }\end{array}$ \\
\hline
\end{tabular}

Framing Strategies Leading to Persuading Strategies

The metro rail megaproject had to acquire land from multiple stakeholders, such as airports, the existing suburban rail organisation, religious groups and from the general public. With the airport authority, the project team stressed the framing of interconnectivity between services, which they propagated in the news articles. By stressing this frame, they argued that both the airport authority and the metro rail would eventually gain from interconnecting their services. Doing this acted

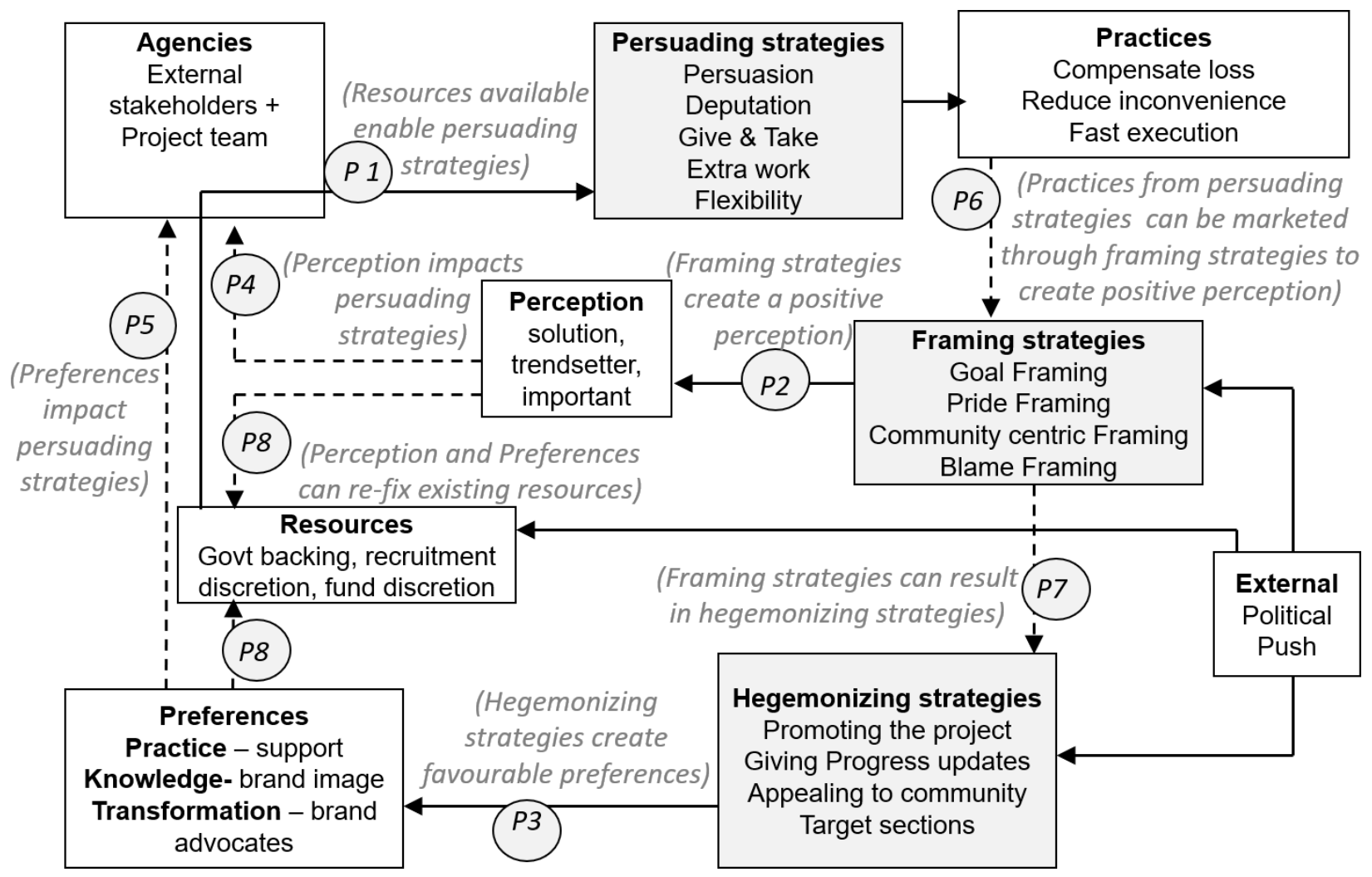

Figure 3 Circuitry framework in external stakeholder management.

Engineering Project Organization Journal

(C) 2018 Engineering Project Organization Society

www.epossociety.org 
as a precursor for the persuading strategy, which finally led to the metro rail constructing an extra parking facility for airport employees in exchange for permission to construct the metro rail station on airport land. A similar instance was observed with the suburban rail networks as the metro rail project again stressed interconnectivity between the existing suburban rail network and the metro rail network that was under-construction. The persuading strategy resulted in the metro rail organisation building an extension station for the suburban network in exchange for permission to build its own station on rail land owned by the suburban railway.

In acquiring land from religious groups, the metro rail organisation projected the message that the project was designed for the benefit of the people. They did so by relying on the framing strategies propagated through news articles. When the project team pitched the 'public good' frame (as well as providing adequate compensation) religious groups agreed to give up land to the project. The Public Relations Officer (PRO) of the project remarked,

"Religious buildings are always a big problem for all projects. We [metro rail organization] tried to make them understand that this was for the people, so ultimately, the trustees understood how things are working out. We compensated them well ... and they were happy with it"

Similarly, in acquiring land from the general public, the project organisation persuaded them to accept the market rate compensation and give the land as a public good, stressing that the metro rail was ultimately for the community. Similarly to the works of Chong and Wolinsky-Nahmias (2005), associating a programme with universally supported goals, such as 'clean drinking water', can help in land acquisitions. The 'public good' frame also helped employees of external stakeholder governmental agencies, such as utility companies, railways, etc., feel attached to the project and thereby fostered better cooperation. These stakeholders considered the project as a 'public good' and supported the speedy completion of the project. From the above instances, we posit that,

Proposition 4 (P4): The perception of the megaproject enabled by the framing strategies, along with the resources available to the project team, have a direct impact on the megaproject team's overt strategic action.

\section{Hegemonizing Strategies Leading to Per- suading Strategies}

Since the metro rail megaproject had a significant number of elevated stretches, they had to create road diversions during construction, leading to disturbances to the road users. These situations are ideal grounds for public protests and user resistance and dissent. To please the project community disrupted by these diversions, the project had to create more efficient and less disruptive diversions. The project team, through its branding and hegemonizing effects, were able to reach out to the public and alter their preferences and reconcile them to the current diversions without protests. The human resource manager reflected on the community sentiments as follows,

"When we [metro rail organization] create
traffic diversions for work ... There is no
agitation from public ... They [project
community] have accepted us."

The acceptance of the project by the community subsequent to the hegemonizing strategies helped the project satisfy these stakeholders with little or no investment through persuading strategies. This is similar to the findings of Orr and Scott (2008) who note that effective stakeholder management can bring about a reduction in the direct operational cost in the project. In the case of the metro rail project, a few members of the community insisted that the project could divert this investment towards the maintenance of metro rail project's assets instead. For instance, during the initial days of the metro rail operation, when the metro rail feeder services were free, a member of the project community commented,

"You can plan some collection box. Just give
as you like... This amount can be used for

Engineering Project Organization Journal

(C) 2018 Engineering Project Organization Society www.epossociety.org 
charity or metro maintenance purpose." (Quoted from the comments on a Facebook post of 12th October 2017)

Thus, seeing the role of these preferences of the project community in the persuading strategies, we posit that,

Proposition 5 (P5): The preferences of the megaproject community established in hegemonizing strategies enable overt strategic action, in concert with the resources available to the project team.

This proposition is supported by Henisz (2016), wherein he highlights that megaproject teams should look for points of similarity, such as affinity of sports, culture, etc., and build initial dialogues around them. In the metro rail megaproject, the project team used social media to propagate similarities that the project shared with the interests of external stakeholders by celebrating national and regional festivals. They also showed community concern as the project invested in weaker sections of the population and gave free rides to school children. These strategies helped connect the megaproject with the community, leading to favourable dialogue and support from the community for the construction activities of the megaproject.

Together, both perceptions of the megaproject and the preferences of the stakeholders shape the visible persuading strategies. Supporting this, Mok et al. (2015) highlight that stakeholder perception and behaviours are important considerations of external stakeholder management in these megaprojects. They note that the stakeholders are affected by the values and assumptions deeply embedded in the stakeholders' consciousness.

\section{Persuading Strategies Leading to Fram- ing and Hegemonizing Strategies}

Solar panels were installed in response to the community raising objections to the project tapping into the energy source in an electricity deficient city. The project agreed to install the solar panels as extra work to address a non-project related concern of the community, in order to persuade stakeholders to support the project. The project organisation was then able to frame the use of solar panels in the metro rail project as one of the largest in India, highlighting environmental stewardship. Thus, this framing strategy was a result of the persuading strategy. Supporting this, Derakhshan et al. (2019) claim that community experiences with the project organisation influence its legitimacy. Thus, we posit that,

Proposition 6 (P6): The use of persuading strategies is highlighted and marketed through framing strategies to create positive perceptions of the project.

Entman (2004) notes that contested matters are difficult to frame and the frames that are incongruent with dominant schemas are blocked from spreading by a common culture. This can be seen in work on the Westconnex project by Mangioni (2018), in which he highlights the ways that land was acquired for the project and how the property owners concerned were unable to relocate themselves, due to lack of support from the project. A negative perception of the project resulted in media representations and, as the acquisitions progressed, the community became aware of the flawed relocation policies and did not agree to further acquisition voluntarily. He notes that the phenomenon of people not voluntarily giving up their land is evident in the significant increase in the number of properties the project acquired by compulsion. Thus, the particulars of dissatisfied stakeholders are difficult to frame and, if they are framed, tend to be blocked from spreading, as Entman (2004) notes. A positive public perception of a project is possible only if the stakeholders are dealt with in a satisfactory manner through the persuading strategies and if these strategies are made known to the public through positive framing strategies.

To acquire land from the church authorities, the project team agreed to renovate parts of the church as part of their persuading strategy. The church gave up a small portion of their land for the piers of the metro rail network, in exchange for which the metro rail undertook the renovations. The metro rail organisation took credit for this work and framed it as a Corporate Social Responsibility (CSR) activity. A tweet by the project organisation read, 
"*** [metro rail organization] repaired and beautified the *** Church at *** [name of place] and was handed over to the church authorities" (Tweet by the metro rail organization on 18 June 2014)

Thus, the CSR activities complemented the framing and hegemonizing strategies. In another instance, when a sewer arch was diverted to enable the construction of the metro rail stations, the metro rail tweeted,

Diversion and Interconnection of Arch Sewer at *** [name of station] Station. An Arch sewer constructed in 1940's... (Tweet by the metro rail organization on 25 October 2012)

Work undertaken did not always disclose the full information and purpose of actions. Sections of the community opposed the metro rail organisation cutting trees to make way for the elevated metro rail viaducts. The organisation was accused of reducing the green cover of the city. The metro rail opted to transplant a few trees to newer locations thereby addressing the grievances of the community. This was tweeted as the project's environmental responsibility.

Successful Transplantation of Trees by *** [name of metro rail organization] - Tree Transplanting involves relocating or moving a tree safely from ... (Tweet by the metro rail organization on 17 April 2012)

When the traffic police department allowed construction of the project only during the night hours so as to cause minimum inconvenience to the flow of traffic, the project team framed it as 'workers toil as city sleeps' in the social media. Such promotion of the organisation created a brand image of a hardworking work culture.

Hence, the adaptations made for the community as part of the persuading strategies were framed and highlighted in the social media as hegemonizing strategies and created a change in the preferences of the project community. Kanji and Agrawal (2016) note that every organisation follows a different strategy to implement CSR activities.
Here, it is seen that the megaproject framed and promoted the work done as part of the persuading strategy as CSR activity; doing so also created hegemonizing effects to help the project in the long-term. Along with fashioning a positive brand image, this resulted in the community supporting construction activities, creating community brand advocates. Thus, we posit that,

Proposition 7 (P7): Effective use of persuading strategies, through framing strategies, results in hegemonizing strategy.

\section{Framing and hegemonizing strategies leading to strengthening of resources}

The megaproject was able to build positive public sentiment by using framing strategies and hegemonizing strategies, creating a positive frame and a positive brand image of the project. The political environment in the state that hosts the project is dominated by two parties. During the feasibility stage of the project the party in power supported the metro rail while the opposition party supported the construction of a monorail on the same route. The metro rail project was selected. As time passed, the opposition party came into power. The positive perception of the community led the opposition party to abandon its sponsorship of the monorail in support of the metro project. Now this party which remains in power is pushing for the next phase of the project they initially opposed. Positive public sentiment led politicians to support the project in the next phase. Other than the state government, the central government also supported the project as quoted by the central minister of India for urban development,

"The Central government will do whatever possible for the expansion of the *** metro rail project" (Quoted from a news article of 14th May 2017)

The positive sentiments from the project community resulted in a prominent funding agency supporting the next phase of the metro rail project. A news media article reported,

"Asked whether he was satisfied with the
progress of implementation of the first 
phase of the Metro Rail project, Mr. *** [name of representative from the funding foreign country] termed the project "very important" and replied, "I hope to see early completion of the project ... On that basis, we are ready to look into the project [phase 2 of the metro rail project] in a very serious manner" (Quoted from a news article of 15th July 2017)

Thus, the successful management of external stakeholders and support from the project community ensured that the resources that the project team possessed in the form of fund discretion from the financiers and government backing from the politicians were all maintained to further enable persuading strategies. Also, since the project enjoyed legitimacy due to the framing strategies used, the resource usage of the project was not questioned, supporting Hooge and Dalmasso (2015) note that success of stakeholders for resource decisions depends on their perceived legitimacy. Hence, we posit that,

Proposition 8 (P8): The perception of the megaproject expressed through the preferences of the local community results in re-fixing the existing resources of the megaproject.

Thus, as seen in the framework in Figure 3, megaprojects start with a political push which helps attaining resources that enable the persuading strategies, as seen in P1. Framing strategies create a perception of the project, as seen in P2. Hegemonizing strategies create a change in preferences of the community, as seen in P3. The positive perception resulting from framing strategies and changes in the preferences of the community resulting from hegemonizing strategies are instrumental in enabling persuading strategies, as seen in P4 and P5 respectively. The use of persuading strategies is highlighted and marketed through framing strategies to create a positive perception of the project, as seen in P6. Also, the effective use of persuading strategies through framing results in hegemonizing as seen in P7. Finally, the perception of the megaproject and the preferences of the project community result in re-fixing the existing resources of the project, as seen in P8. Thus, the framework represents how overt external stakeholder management affects the perception and preferences of the project and how these, in turn, dictate episodically overt strategies in subsequent iterations through the circuits of power.

Anchored in the circuits of power framework (Clegg, 1989), we see the framing strategies as part of the rules of practice and the hegemonizing strategies as part of the techniques of discipline and production. Both of these empower obligatory passage points (OPP) in the form of the perception of the megaproject and the preferences of the external stakeholders and the project team. The agencies of external stakeholders and the project team, control and contest the OPP, thereby creating the first circuit. In the background of these OPP's the project team employed resources to result in the persuading strategies.

Power is dynamic. Power is created, used and maintained through strategies. As seen in Figure 3, the framing and hegemonizing strategies exercise power through creating a favourable perception of the megaproject and constructing favourable preferences within the megaproject team and external stakeholders. Persuading strategies use the power of resources to work on perceptions of the megaproject and the preferences of external stakeholders. The outcome of the persuading strategies results in maintaining power through the framing and hegemonizing strategies. Thus, power is dynamic, and it is these strategies that make power dynamic. While the framing and hegemonizing strategies were instrumental for creating momentum for the project, the persuading strategies were useful for maintaining the momentum and stabilising the power relations.

\section{Conclusion}

From a dimensions of power perspective, we identified three categories of strategies that interact on megaprojects - persuading strategies, framing strategies, and hegemonizing strategies. The persuading strategies resulted in a practice of complying with the needs of external stakeholders, resulting in greater stakeholder satisfaction. The framing strategies resulted in a positive perception of the megaproject and the hegemonizing strategies resulted in a change in the preferences of the project 
community creating support for construction activities and turning the community into brand advocates for the project. We see that practice is dependent on the perceptions and preferences of external stakeholders. Integrating these strategies and effects, we developed a framework that explains external stakeholder management in practice. Understanding strategies through this framework will help project leaders and managers plan and deliver infrastructure megaprojects in a complex environment where there are multiple conflicting objectives from external stakeholders.

Theoretically, the research classified strategies based on the dimensions of power framework (Lukes, 2005) as persuading, framing and hegemonizing strategies. The role of strategy in making power dynamic by creating power, using power and maintaining power extended Freedman's (2013) definition of strategy as the art of creating power. While framing and hegemonizing strategies created power, persuading strategies used the power created. In subsequent iterations of the circuit, all the strategies were effective in maintaining power in the circuit. For project management theory we offer an explanation as to why similar projects with similar resources and personnel perform differently by highlighting the role of external stakeholders' perception and preferences in dictating the overt episodic actions. Also, while the megaprojects literature records the importance of the shaping stage of the project, this research highlights the importance of projects' construction and operation stages. These phases are the longest phases in the project lifecycle and there should be continuous stakeholder engagement in them. Most importantly, this study highlights the dynamic circuitry of stakeholder management. While prior literature has emphasised that the ways external stakeholders are engaged or managed affects the community's perception of the project (Mangioni, 2018), this research highlight that the perception and preferences in subsequent iterations of circuits affects the way external stakeholders are managed. Methodologically, we highlight how naturalistic data, such as news media articles and social media posts, can be effectively used for studying project organisations and their actions. To practice, we recommend megaprojects being vocal in asserting their goals, actions and initiatives as these are vital to creating and maintaining favourable perception of the project and preferences on the part of external stakeholders.

Finally, as in all research there are some limitations. The study focused only on the construction and operation phase of a megaproject and looked at how the project team used persuading, framing and hegemonizing strategies. However, the importance of the shaping phase is stressed in the literature and similar research of this phase is also required. We also acknowledge that other media outlets such as radio, television, pamphlets, etc. can also help in managing external stakeholders and they are also avenues to explore additional power dynamics. We also acknowledge that resistance to the uses of strategy was not part of the scope of this work as we looked only at practices by the project team in relation to external stakeholder management strategies. These strategies will vary with resistance from external stakeholders and hence the dynamic of resistance needs to be investigated further. Other than resistance, external stakeholders may try to meet their needs through the project (Flyvbjerg, 1998), thereby employing their own strategies and power dynamics, something that can also be explored through future research. This study uses qualitative evidence of effectiveness of the strategies used to manage external stakeholders. Future research can explore the use of quantitative measures, such as a frequency count of positive, mixed and negative responses, to show the effectiveness of the use of external stakeholder management strategies. This study records only the strategic use of social media and news articles in managing external stakeholders; however, these communication media can also be a source of productive inputs from external stakeholders, a topic for exploration in future research. Future in-depth research can also be carried out to understand how strategies are generated, triggered, and implemented.

\section{References}

Aaltonen, K. and Sivonen, R. (2009), "Response strategies to stakeholder pressures in global projects", International Journal of Project Management, Vol. 27 No. 2, pp. 131-141.10.1016/j.ijproman.2008.09.007

Engineering Project Organization Journal

(C) 2018 Engineering Project Organization Society www.epossociety.org 
Allen, D. and Kern, T. (2001), "Enterprise resource planning implementation: Stories of power, politics and resistance". In: Russo N. L, Fitzgerald B, Degross J. I, eds, Realigning Research and Practice in Information Systems Development, .-, Boston, Springer, pp. 149-162.

Avelino, F. (2011), Power in transition: empowering discourses on sustainability transitions, Rotterdam, Erasmus University.

Avelino, F. and Rotmans, J. (2009), "Power in transition: an interdisciplinary framework to study power in relation to structural change", European Journal of Social Theory, Vol. 12 No. 4, pp. 543-569.10.1177/1368431009349830

Bachrach, P. and Baratz, M.S. (1962), "Two faces of power", American Political Science Review, Vol. 56 No. 4, pp. 947-952.10.2307/1952796

Backhouse, J., Hsu, C.W. and Silva, L. (2006), "Circuits of power in creating de jure standards: shaping an international information systems security standard", MIS Quarterly, Vol. 30, pp. 413-438.10.2307/25148767

Callon, M. (1984), "Some elements of a sociology of translation: domestication of the scallops and the fishermen of St Brieuc Bay", The Sociological Review, Vol. 32 No. 1_suppl, pp. 196-233.10.1111/j.1467-954X.1984.tb00113.x

Chinyio, E.A. and Akintoye, A. (2008), "Practical approaches for engaging stakeholders: findings from the UK", Construction Management and Economics, Vol. 26 No. 6, pp. 591599.10.1080/01446190802078310

Chong, D. and Wolinsky-Nahmias, Y. (2005), "Green fees: the price of open space". In: Martinez M. D, Craig S. C, eds, Ambivalence, Politics and Public Policy, . -, New York, Palgrave, pp. 103-125.

Clegg, S. (1975), Power, rule and domination: A critical and empirical understanding of power in sociological theory and organizational life, London, Routledge.

Clegg, S.R. (1989), Frameworks of power, London, Sage.

Clegg, S.R., Courpasson, D. and Phillips, N. (2006), Power and organizations. Thousand Oaks, CA, Sage.

Clegg, S. R., Haugaard, M.. eds (2009) The Sage handbook of power, Sage, London.

Clegg, S. and Kornberger, M. (2015), “Analytical frames for studying power in strategy as practice and beyond". In: Golsorkhi D, Rouleau L, Seidl D, Vaara E, eds, The Cambridge Handbook on Strategy-as-Practice, .-, Cambridge: UK, Cambridge University Press, pp. 389-404.
Clegg, S.R. and Kreiner, K. (2013), "Power and Politics in Construction Projects". In: Drouin N, Muller R, Sankaran S, eds, Novel Approaches to Organizational Project Management Research, .-, Copenhagen, Copenhagen Business School Press, pp. 268-293.

Dahl, R.A. (1957), "The concept of power", Behavioral Science, Vol. 2 No. 3, pp. 201-215.10.1002/ bs.3830020303

Derakhshan, R., Mancini, M. and Turner, J.R. (2019), “Community's evaluation of organizational legitimacy: Formation and reconsideration", International Journal of Project Management, Vol. 37 No. 1, pp. 73-86.10.1016/j.ijproman.2018.10.004

Eisenhardt, K.M. (1989), "Building theories from case study research", Academy of Management Review, Vol. 14 No. 4, pp. 532-550.10.5465/ amr.1989.4308385

Entman, R.M. (1993), "Framing: toward clarification of a fractured paradigm", Journal of Communication, Vol. 43 No. 4, pp. 51-58.10.1111/j.1460-2466.1993. tb01304.x

Entman, R.M. (2004), Projections of Power. Framing News, Public Opinion and U.S. Foreign Policy, Chicago, The University of Chicago Press.

Fleming, P. and Spicer, A. (2007), Contesting the corporation: Struggle, power and resistance in organizations, Cambridge University Press.

Fleming, P. and Spicer, A. (2014), "Power in management and organization science", Academy of Management Annals, Vol. 8 No. 1, pp. 237298.10.5465/19416520.2014.875671

Flyvbjerg, B. (1998), Rationality and power: Democracy in practice, Chicago, University of Chicago press.

Flyvbjerg, B. (2014), "What you should know about Megaprojects and why: an overview", Project Management Journal, Vol. 45 No. 2, pp. 6-19.10.1002/ pmj.21409

Flyvbjerg, B., Bruzelius, N. and Rothengatter, W. (2003), Megaprojects and risk: An anatomy of ambition, Cambridge University Press.

Flyvbjerg, B., Garbuio, M. and Lovallo, D. (2009), "Delusion and deception in large infrastructure projects: two models for explaining and preventing executive disaster", California Management Review, Vol. 51 No. 2, pp. 170-194.10.2307/41166485

Foucault, M. (1977), Discipline and punish: The birth of the prison. Trans. Sheridan A, London, Penguin Books.

Freedman, L. (2013), Strategy. A History, Oxford and New York, Oxford University Press. 
Frick, K.T. (2008), "The cost of the technological sublime: Daring ingenuity and the new San Francisco-Oakland Bay Bridge". In: Priemus H, Flyvbjerg B, van Wee B, eds, Decision-making on mega-projects: Cost-benefit analysis, planning and innovation, .-, Cheltenham, UK, Edward Elgar, pp. 239-262.

Geraldi, J. and Söderlund, J. (2018), "Project studies: what it is, where it is going", International Journal of Project Management, Vol. 36 No. 1, pp. 55-70.10.1016/j.ijproman.2017.06.004

Gil, N.A. and Lundrigan, C. (2012), The leadership and governance of megaprojects, Manchester, Manchester University.

Goffman, E. (1974), Frame analysis: An essay on the organization of experience, Harvard University Press.

Golden-Biddle, K. and Locke, K.D. (1997), Composing Qualitative Research. Thousand Oaks, CA, SAGE.

Gramsci, A. (1971), Selections from the Prison Notebooks of Antonio Gramsci. Translated by Q. Hoare and G. Nowell-Smith, New York, International Publishers.

Hardy, C. (1996), "Understanding power: bringing about strategic change", British Journal of Management, Vol. 7 No. 1 S3S16.10.1111/j.1467-8551.1996.tb00144.x

Henisz, W.J. (2016), "The dynamic capability of corporate diplomacy", Global Strategy Journal, Vol. 6 No. 3, pp. No. 183-196.10.1002/gsj.1121

Henisz, W.J. (2017), Corporate diplomacy: Building reputations and relationships with external stakeholders, Routledge.

Heracleous, L. and Barrett, M. (2001), “Organizational change as discourse: communicative actions and deep structures in the context of information technology implementation", Academy of Management Journal, Vol. 44 No. 4, pp. 755-778.

Hooge, S. and Dalmasso, C. (2015), "Breakthrough R\&D stakeholders: The challenges of legitimacy in highly uncertain projects", Project Management Journal, Vol. 46 No. 6, pp. 54-73.

Iyengar, S. and Simon, A. (1993), "News coverage of the Gulf crisis and public opinion: a study of agenda-setting, priming and framing", Communication research, Vol. 20 No. 3, pp. 365-383.

Kanji, R. and Agrawal, R. (2016), "Models of corporate social responsibility: comparison, evolution and convergence", IIM Kozhikode Society \& Management Review, Vol. 5 No. 2, pp. 141155.10.1177/2277975216634478
Kim, W.C. and Mauborgne, R. (2003), "Fair process: managing in the knowledge economy", Harvard Business Review, Vol. 81 No. 1, pp. 127-136.

Kornberger, M. and Clegg, S. (2011), "Strategy as performative practice: the case of Sydney 2030", Strategic Organization, Vol. 9 No. 2, pp. 136-162.

Lapsley, I. and Giordano, F. (2010), "Congestion charging: a tale of two cities", Accounting, Auditing \& Accountability Journal, Vol. 23 No. 5, pp. 671-698.10.1108/09513571011054936

Liu, B., Li, Y., Xue, B., Li, Q., Zou, P.X.W. and Li, L. (2018), "Why do individuals engage in collective actions against major construction projects? -An empirical analysis based on Chinese data", International Journal of Project Management, Vol. 36 No. 4, pp. 612-626.10.1016/j.ijproman.2018.02.004

Lukes, S. (1974), Power: A radical view, London, Macmillan.

Lukes, S. (2005), Power: A radical view. The original text with two major new chapters.

Mahalingam, A. and Vyas, A. (2011), "Comparative evaluation of land acquisition and compensation processes across the world", Economic and Political Weekly, Vol. 46 No. 32, pp. 94-102.

Mangioni, V. (2018), "Evaluating the impact of the land acquisition phase on property owners in megaprojects", International Journal of Managing Projects in Business, Vol. 11 No. 1, pp. 158173.10.1108/IJMPB-08-2017-0090

Mitchell, R.K., Agle, B.R. and Wood, D.J. (1997), “Toward a theory of Stakeholder identification and salience: defining the principle of who and what really counts", Academy of Management Review, Vol. 22 No. 4, pp. 853-886.10.5465/amr.1997.9711022105

Mok, K.Y., Shen, G.Q. and Yang, J. (2015), “Stakeholder management studies in mega construction projects: a review and future directions", International Journal of Project Management, Vol. 33 No. 2, pp. 446-457.10.1016/j.ijproman.2014.08.007

$\mathrm{Ng}$, A. and Loosemore, M. (2007), "Risk allocation in the private provision of public infrastructure", International Journal of Project Management, Vol. 25 No. 1, pp. 66-76.10.1016/j.ijproman.2006.06.005

Ninan, J., Clegg, S. and Mahalingam, A. (2019a), "Branding and governmentality for infrastructure megaprojects: the role of social media", International Journal of Project Management, Vol. 37 No. 1, pp. 59-72.10.1016/j.ijproman.2018.10.005

Ninan, J., Mahalingam, A. and Clegg, S. (2019b), "External Stakeholder management strategies and resources in Megaprojects: an organizational power

Engineering Project Organization Journal

(C) 2018 Engineering Project Organization Society www.epossociety.org 
perspective", Project Management Journal, Vol. 50 No. 6, pp. 625-640.10.1177/8756972819847045

Orr, R.J. and Scott, W.R. (2008), "Institutional exceptions on global projects: a process model", Journal of International Business Studies, Vol. 39 No. 4, pp. 562-588.10.1057/palgrave.jibs. 8400370

Plowman, K.D. (1998), "Power in conflict for public relations", Journal of Public Relations Research, Vol. 10 No. 4, pp. 237-261.10.1207/s1532754xjprr1004_02

Queiroz, C.A. and Gautam, S. (1992), Road infrastructure and economic development: some diagnostic indicators (Vol. 921, World Bank Publications.

Schildt, H., Mantere, S. and Cornelissen, J. (2019), "Power in Sensemaking Processes. Organization Studies", Vol. 0170840619847718.

Scott, W.R. (1965), "Field methods in the study of organizations.”, J. G. March, Chicago, Handbook of organizations, Rand McNally.

Smith, S., Winchester, D., Bunker, D. and Jamieson, R. (2010), "Circuits of Power: A Study of Mandated Compliance to an Information Systems Security "De Jure" Standard in a Government
Organization", MIS Quarterly, Vol. 34 No. 3, pp. 463-486.10.2307/25750687

Spradley, J.R. (1979), The ethnographic interview, New York, Harcourt Brace Jovanovich.

Söderlund, J. (2011), "Pluralism in project management: Navigating the crossroads of specialization and fragmentation", International Journal of Management Reviews, Vol. 13 No. 2, pp. 153-176.10.1111/j.1468-2370.2010.00290.x

Söderlund, J., Sankaran, S. and Biesenthal, C. (2017), "The past and present of Megaprojects", Project Management Journal, Vol. 48 No. 6, pp. 5-16.10.1177/875697281704800602

Vaara, E., Tienari, J., Piekkari, R. and Säntti, R. (2005), "Language and the circuits of power in a merging multinational Corporation", Journal of Management Studies, Vol. 42 No. 3, pp. 595-623.10.1111/j.14676486.2005.00510.x

Viitanen, K., Falkenbach, H. and Nuuja, K. (2010), Compulsory Purchase and Compensation - Recommendations for Good Practice, Copenhagen, Denmark, International Federation of Surveyors. 